\title{
ANALISIS PROSES BERPIKIR MATEMATIS PESERTA DIDIK DALAM MENYELESAIKAN MASALAH APLIKASI TURUNAN
}

\author{
Arlin Astriyani \\ Universitas Muhammadiyah Purworejo \\ e-mail: arlinastri07@gmail.com
}

\begin{abstract}
ABSTRAK
Setiap peserta didik memiliki kemampuan yang berbeda-beda dalam memecahkan masalah tergantung dari jenis kecerdasan yang dimilikinya. Tujuan penelitian ini adalah untuk menganalisis proses berpikir matematis peserta didik menyelesaikan masalah aplikasi turunan. Penelitian ini menggunakan jenis penelitian kualitatif deskriptif. Subjek penelitian ini terdiri satu orang peserta didik yang dengan rerata hasil belajar paling tinggi. Hasil penelitian menunjukkan bahwa proses berpikir proses berpikir matematis peserta didik dalam menyelesaikan masalah aplikasi turunan menggunakan beberapa tahap penyelesaian berupa : (1) menggaris bawahi apa yang diketahui dalam soal cerita, (2) menghubungkan apa yang diketahui dalam soal dengan apa yang ditanyakan, (3) Mengolah informasi yang diperoleh dari soal, sehingga akan lebih mudah dalam menyelesaikan masalah aplikasi turunan.
\end{abstract}

Kata kunci: Berpikir matematis, masalah aplikasi turunan, matematika

\section{PENDAHULUAN}

Pembelajaran merupakan proses interaksi peserta didik dengan pendidik dan sumber belajar pada suatu lingkungan belajar (Rustaman, 2001). Pembelajaran merupakan bantuan yang diberikan pendidik agar dapat terjadi proses perolehan ilmu dan pengetahuan, penguasaan kemahiran dan tabiat, serta pembentukan sikap dan kepercayaan pada peserta didik. Pembelajaran yang berkualitas sangat tergantung dari motivasi pelajar dan kreatifitas pengajar. Pembelajaran yang memiliki motivasi tinggi ditunjang dengan pengajar yang mampu memfasilitasi motivasi tersebut akan membawa pada keberhasilan pencapaian target belajar. Target belajar dapat diukur melalui perubahan sikap dan kemampuan peserta didik melalui proses belajar. Desain pembelajaran yang baik, ditunjang fasilitas yang memandai, ditambah dengan kreatifitas guru akan membuat peserta didik lebih mudah mencapai target belajar. Standar kompetensi lulusan dan kompetensi inti yang dirumuskan menyiratkan secara jelas bahwa tujuan pembelajaran matematika dewasa ini menekankan pada 
kemampuan berpikir yang harus dimiliki peserta didik. Dengan memiliki kemampuan berpikir, maka peserta didik akan lebih baik dalam memahami dan menguasai konsepkonsep matematika yang dipelajarinya. Untuk membekali peserta didik, maka pembelajaran matematika dewasa ini seharusnya difokuskan pada upaya untuk melatih peserta didik menggunakan potensi berpikir yang dimiliki. Selain itu, Soedjadi (2000) menyatakan bahwa objek dasar matematika yang merupakan fakta, konsep, relasi/operasi dan prinsip merupakan hal-hal yang abstrak sehingga untuk memahaminya tidak cukup hanya dengan menghafal tetapi dibutuhkan adanya proses berpikir. Dengan demikian maka pembelajaran matematika seharusnya memberikan penekanan pada proses berpikir peserta didik.

Berdasarkan fakta di lapangan yang masih menunjukkan bahwa pembelajaran matematika hanya terlihat sebagai suatu kegiatan yang monoton dan prosedural, yaitu guru menerangkan materi, memberi contoh, menugaskan peserta didik untuk mengerjakan latihan soal, mengecek jawaban peserta didik secara sepintas, selanjutnya membahas pemecahan soal yang kemudian dicontohi oleh peserta didik. Aspek esensial dari pembelajaran, yaitu proses berpikir peserta didik, seolah-olah diabaikan. Dampak dari kondisi ini mengakibatkan banyak peserta didik yang tidak dapat memahami konsep-konsep matematika dengan baik sehingga cenderung memperoleh hasil belajar matematika yang kurang memuaskan, dan indikasi dari hal ini terlihat jelas pada hasil ujian nasional untuk mata pelajaran matematika pada jenjang pendidikan dasar hingga menengah. Proses yang terjadi dalam aktivitas belajar melibatkan proses mental yang terjadi dalam otak peserta didik, sehingga belajar merupakan aktivitas yang selalu terkait dengan proses berpikir. Sieger (Santrock, 2004) menyatakan bahwa berpikir adalah pemrosesan informasi. Ketika anak merasakan (perceive), melakukan penyandian (encoding), merepresentasikan, dan menyimpan informasi dari dunia sekelilingnya, maka mereka sedang melakukan proses berpikir. Untuk dapat merangsang dan melatih kemampuan berpikir peserta didik dalam pembelajaran matematika, maka perlu digunakan cara atau teknik yang tepat dalam pembelajaran yang dapat merangsang peserta didik untuk menggunakan segenap potensi berpikir yang dimiliki. Pemecahan masalah merupakan cara yang tepat dalam 
pembelajaran untuk melatih peserta didik berpikir dan hal ini sudah dibuktikan para ahli melalui sejumlah penelitian. NCTM (2010) menyatakan bahwa "problem solving plays an important role in mathematics and should have a prominent role in the mathematics education." Pendapat tersebut berarti bahwa pemecahan masalah memainkan peranan penting dalam matematika dan seharusnya mempunyai peranan utama dalam pendidikan matematika.

Berdasarkan pengalaman peneliti, dalam memecahkan masalah matematika ditemukan bahwa ada peserta didik yang menunjukkan kemampuan yang sangat baik, ada peserta didik yang menunjukkan kemampuan yang biasa saja, dan ada peserta didik yang mengalami kesulitan. Dalam memecahkan masalah, hampir sebagian besar peserta didik menuliskan langkah-langkah sistematis, yaitu diawali dengan menuliskan yang diketahui dan ditanyakan dan selanjutnya menyelesaikan masalah. Meskipun menunjukkan kesamaan dalam menuliskan langkah-langkah pemecahan masalah yang sistematis, namun perbedaan terlihat dalam hal mengidentifikasi hal yang diketahui dan ditanyakan dari sebuah soal pemecahan masalah yang berimplikasi pada perbedaan dalam menyelesaikan masalah. Fakta ini menunjukkan adanya faktor-faktor kognitif yang berbeda diantara peserta didik tersebut yang mempengaruhi kemampuan pemecahan masalah. Dalam memecahkan masalah matematika, setiap orang memiliki cara dan gaya berpikir yang berbeda-beda karena tidak semua orang memiliki kemampuan berpikir yang sama.

Beberapa ahli menemukan beberapa cara dalam menyelesaikan masalah matematika, diantaranya adalah Polya. Langkah-langkah dalam memecahkan masalah menurut Polya diantaranya adalah analyzing and understanding a problem, designing and planning a solution, exploring solution to difficult problem, verifying a solution. Langkah pertama dalam pemecahan masalah matematika menurut Polya, yaitu analyzing and understanding a problem (menganalisis dan memahami masalah). Pada langkah ini, peserta didik harus dapat menganalisis dan memahami masalah yang ada dengan cara menetukan dan mencari apa yang diketahui dan apa yang ditanyakan pada masalah tersebut. Langkah kedua yaitu designing and planning a solution (merancang dan merencanakan solusi). Pada langkah ini, peserta didik harus dapat 
merancang dan merencanakan solusi yang ada berdasarkan apa yang telah diketahui dan ditanyakan pada masalah sesuai dengan langkah pertama. Langkah ke tiga yaitu exploring solution to difficult problem (mencari solusi dari masalah). Pada langkah ini, peserta didik harus menentukan solusi untuk dapat menyelesaikan permasalahan yang ada sesuai dengan rencana yang telah dibuat pada langkah kedua. Langkah ke empat yaitu verifying a solution (memeriksa solusi). Pada langkah ini peserta didik harus dapat memeriksa kembali hasil yang telah diperoleh, apakah jawabanya sudah benar dan sesuai dengan apa yang ditanyakan pada masalah atau belum (Widyastuti, 2015).

Adanya suatu masalah umumnya mendorong peserta didik untuk dapat memecahkan masalah dengan segera namun tidak tahu secara langsung bagaimana menyelesaikannya (Fatmawati, Mardiyana dan Triyanto, 2014). Saat memecahkan masalah, peserta didik melakukan proses berpikir dalam benak sehingga peserta didik dapat sampai pada jawaban. Sebagaimana menurut Herman Hudojo dalam (Argarini, Budiyono, dan Sujadi, 2014) menyatakan bahwa dengan pemecahan masalah individu akan berlatih memproses data atau informasi. Pemrosesan data atau informasi itu disebut berpikir. Sangat penting bagi guru untuk mengetahui proses berpikir peserta didik dalam menyelesaikan suatu masalah matematika sehingga guru dapat mengetahui jenis dan letak kesalahannya. Hasil pengamatan terhadap kondisi peserta didik diperoleh kesimpulan bahwa setiap peserta didik selalu mempunyai perbedaan. Perbedaan harus diterima dan dimanfaatkan dalam belajar. Kesalahan yang dilakukan peserta didik dapat dijadikan sumber informasi belajar dan pemahaman bagi peserta didik itu sendiri. Kesalahan yang dilakukan oleh peserta didik pasti sangat beragam, oleh karena itu proses berpikirnya pun pasti tidaklah sama (Hasanah, Mardiyana dan Sutrima, 2013). Penelitian tentang deskriptif kemampuan berpikir telah dilakukan oleh (Dodi, Hudiono dan Suratman, 2015). Hasil penelitian menyimpulkan bahwa peserta didik memiliki kemampuan berpikir dengan berbagai tingkatan, dan peserta didik ratarata memiliki kemampuan berpikir tingkat rendah.

Penelitian proses berpikir dalam pemecahan masalah matematika telah banyak dilakukan. Peneliti tertarik untuk melakukan penelitian yaitu tentang analisis proses berpikir matematis peserta didik menyelesaikan masalah aplikasi turunan. 


\section{METODE PENELITIAN}

Penelitian ini dilaksanakan di Fakultas IImu Pendidikan Universitas Muhammadiyah Jakarta. Penelitian ini menggunakan metode penelitian kualitatif deskriptif. Metode penelitian kualitatif adalah metode penelitian yang digunakan untuk meneliti pada kondisi obyek yang alamiah, dimana peneliti adalah sebagai instrumen kunci, teknik pengumpulan data dilakukan secara triangulasi (gabungan) dan hasil penelitian kualitatif lebih menekankan makna dari pada generalisasi (Sugiyono, 2014). Subjek dalam penelitian ini adalah satu orang mahasiswa pendidikan matematika semester 3 Tahun Ajaran 2019/2020 dengan dengan rerata hasil belajar A dan IPK di atas 3,5. Teknik pengumpulan data menggunakan observasi dan dokumentasi. Kemudian, data yang telah dikumpulkan ditriangulasikan menggunakan triangulasi teknik dan dianalisis menggunakan analisis data Model Miles dan Huberman. Model Miles dan Huberman (Sugiyono, 2014) memiliki aktivitas yang dilakukan, yaitu: pengumpulan data, reduksi data, display data, dan verifikasi / penarikan kesimpulan.

\section{PEMBAHASAN}

Berdasarkan 3 soal cerita tentang aplikasi turunan yang diberikan kepada subjek yang berupa:

Sebuah kertas undangan memuat $300 \mathrm{~cm}$ persegi bahan cetak. Jika margin atas bawah kanan kiri masing-masing $3 \mathrm{~cm}$. Tentukan ukuran selebaran yang memerlukan kertas sedikit mungkin.

Jawaban dari subjek: 


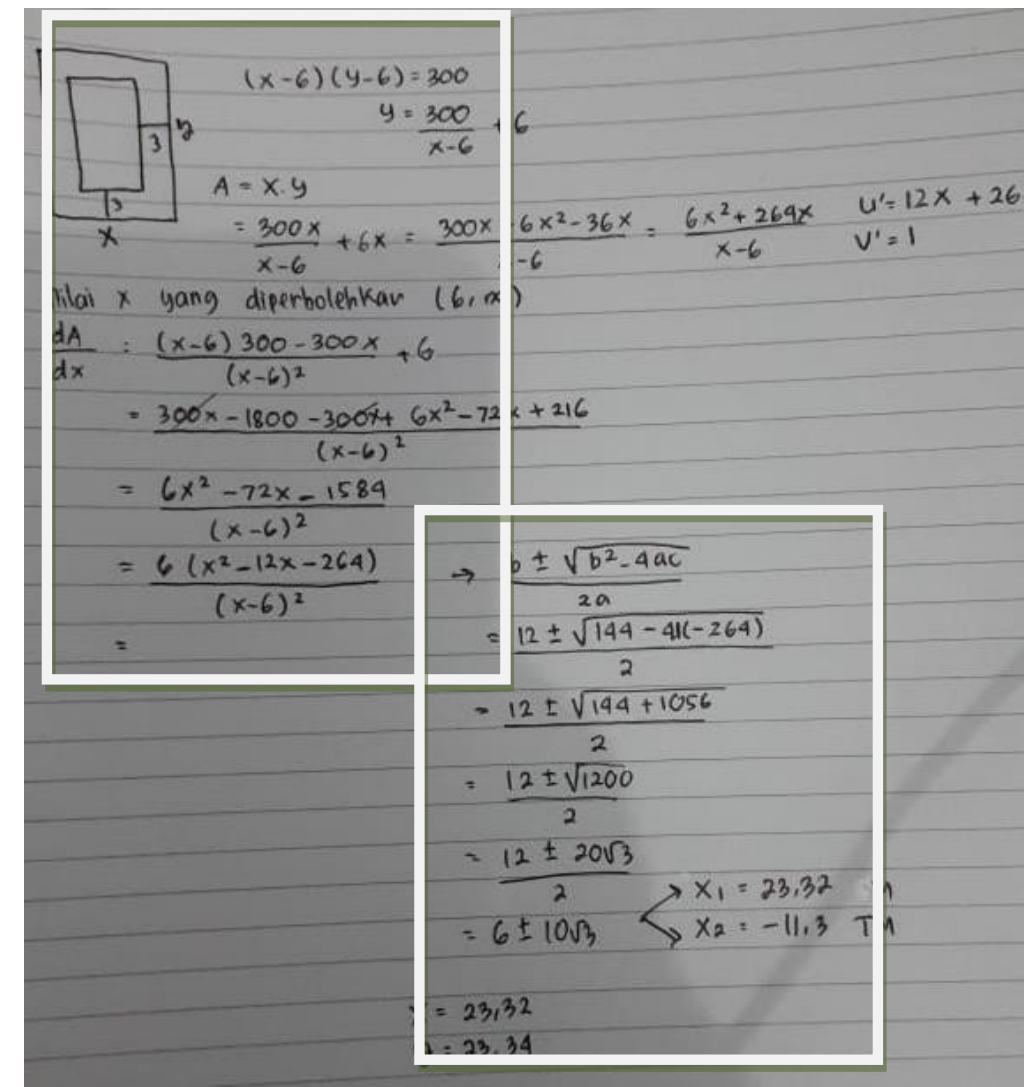

Gambar 1. Hasil Pekerjaan Subjek 1

Berdasarkan permasalahan di atas, subjek menggambarkan terlebih dahulu disertai ukuran yang diketahui dalam soal. Kemudian subjek menuliskan rumus luas karton setelah dikurangi dengan margin atas 3, bawah 3, kanan 3 dan kiri 3. Setelah dibuat y sama dengan kemudian dituliskan kembali luas karton dengan mengalikan $\mathrm{x}$ dengan y. Setelah diperoleh luas kemudian dicari batasan untuk nilai x nya. Setelah langkah tersebut, subjek menurunkan luas terhadap $\mathrm{x}$ untuk mencari titik kritis dan untuk meminimalkan bahan cetak untuk membuat kertas undangan. Setelah memfaktorkan untuk mencari nilai $x$ ang memenuhi, kemudian subjek mensubtitusikan nilai $x$ yang sudah ditemukan terhadap $y$, sehingga diperoleh $x=23,32 \mathrm{~cm}$ tetapi untuk nilainya subjek kurang tepat dalam perhitungan sehingga diperoleh $\mathrm{y}=23,34 \mathrm{~cm}$ yang seharusnya $y=23,32 \mathrm{~cm}$.

Kotak sepatu dibuat dari selembar kertas karton panjang $30 \mathrm{~cm}$, lebar $15 \mathrm{~cm}$ dan jika tingginya $x$, cari ukuran karton agar volumenya maksimum.

Jawaban subjek: 


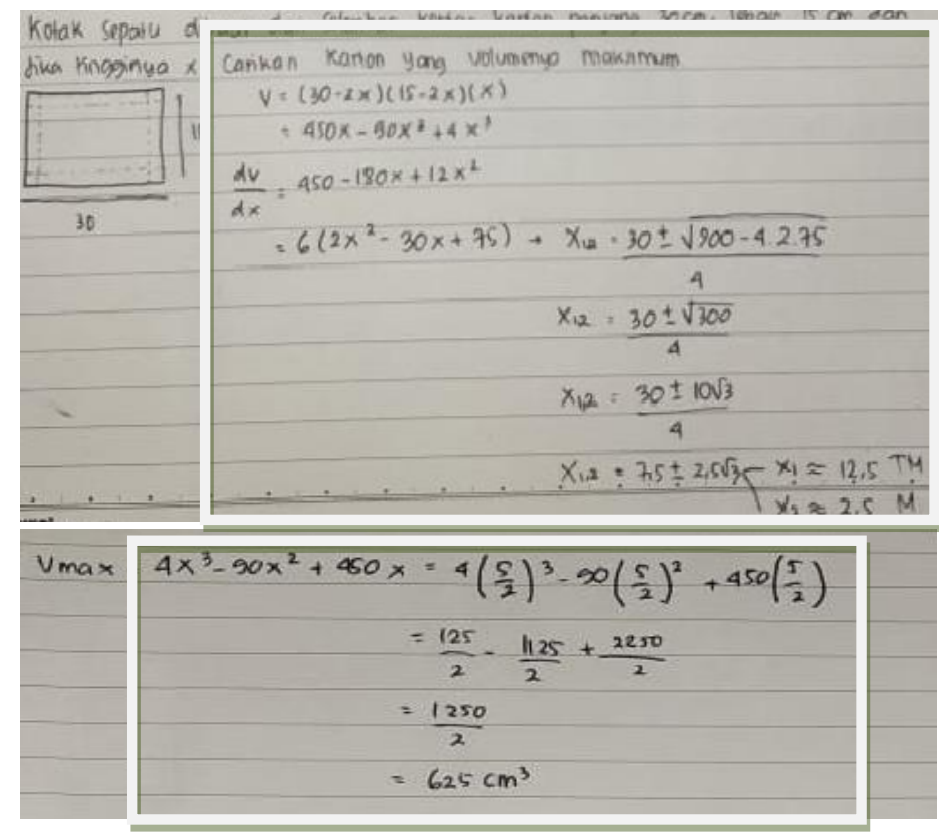

Gambar 2. Hasil Pekerjaan Subjek 2

Berdasarkan soal cerita dan cara subjek menyelesaikan masalah terlihat bahwa subjek menggambarkan terlebih dahulu apa yang diketahui, menggaris bawahi apa yang diketahui dalam soal cerita. Kemudian setelah itu menghubungkan apa yang diketahui dalam soal seperti panjang karton $30 \mathrm{~cm}$ an lebar karton $15 \mathrm{~cm}$ dan tinggi $x$ untuk membuat kotak sepatu dengan apa yang ditanyakan yaitu ukuran karton agar volumenya maksimum. Setelah itu mengolah informasi yang diperoleh dari soal, dengan cara menuliskan volume kotak kemudian menurunkan volume terhadap $\mathrm{x}$ untuk mencari titik kritis. Setelah titik kritis ditemukan dan dipilih yang memenuhi kemudian disubstitusikan terhadap rumus volume sehingga diperoleh volume maksimal $625 \mathrm{~cm}^{3}$.

Seorang peternak mempunyai kawat berduri sepanjang 90 meter dimana kandang ayamnya terlihat seperti gambar di bawah ini. Carilah ukuran kandang agar luasnya maksimum.

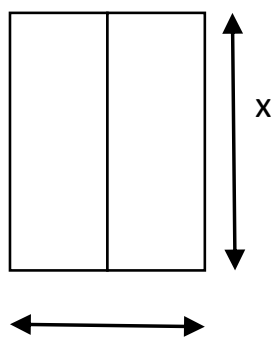

y 
Jawaban subjek:

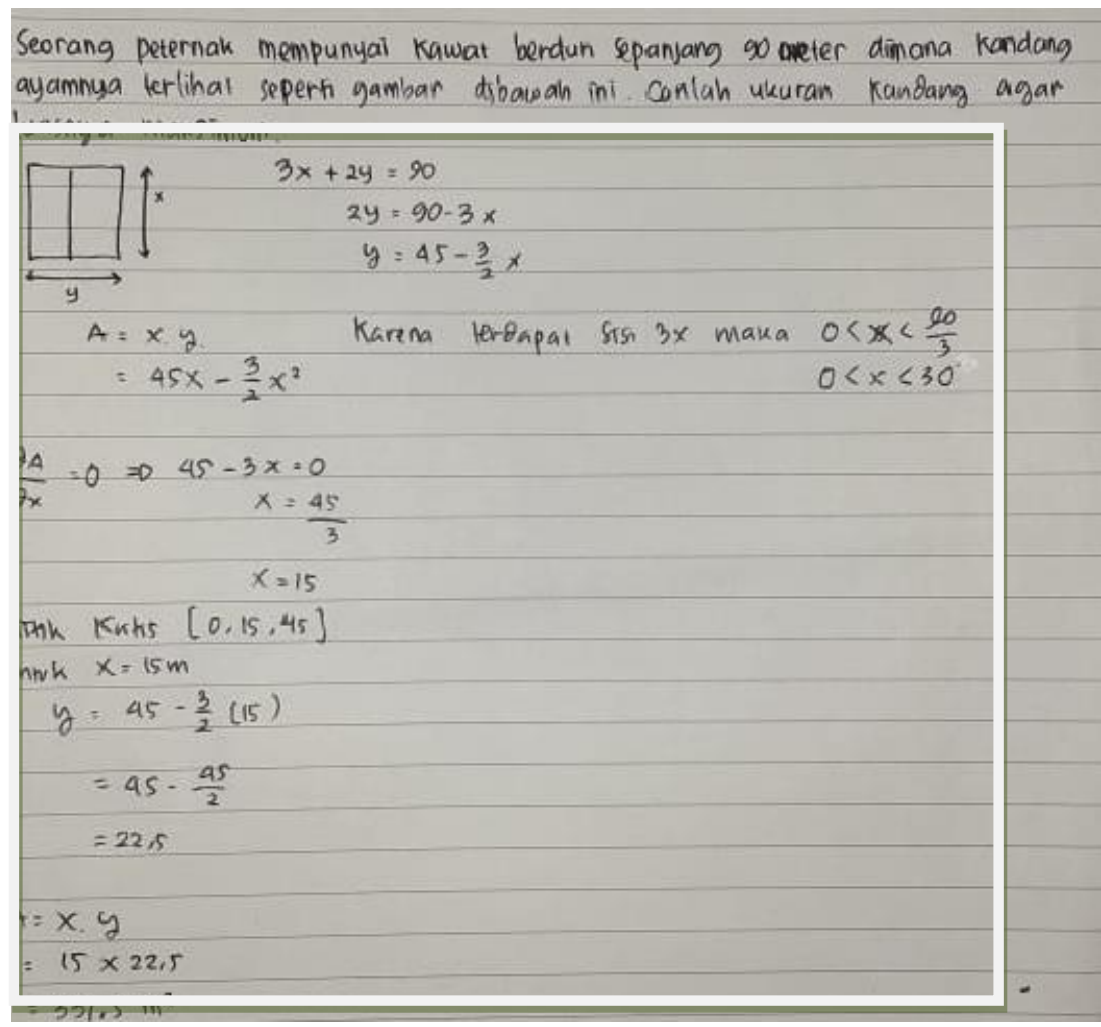

Gambar 2. Hasil Pekerjaan Subjek 3

Berdasarakan hasil pekerjaan siswa, langkah pertama yang dilakukan subjek adalah menggambar ulang dari soal yang telah diketahui. Dari soal, subjek menuliskan keliling kawat tersebut yaitu $3 x+2 y=90$ dan diubah ke y sama dengan. Tahap selanjutnya berdasarkan soal, subjek menuliskan rentang nilai untuk x yaitu $0<x<30$. Setelah diperoleh y sama dengan, kemudian subjek mengalikan $\mathrm{x}$ dan y untuk mencari luas kandang. Luas yang diperoleh kemudian diturunkan terhadap $\mathrm{x}$ untuk memasksimalkan luas dan untuk mencari nilai $x$ yang memenuhi. Setelah diturunkan diperoleh $\mathrm{x}=15 \mathrm{~m}$ kemudian disubstitusikan nilai $\mathrm{x}$ tersebut ke dalam y sehingga diperoleh $y=22,5 \mathrm{~m}$. Dari nilai $x$ dan y yang sudah diperoleh disubstitusikan ke dalam rumus luas untuk mencari luas kandang daan diperoleh luas kandang adalah $337,5 \mathrm{~m}^{2}$ Kemudian berdasarkan 3 soal cerita di atas, subjek terlihat dapat menyelesaikan permasalahan hanya pada soal cerita nomer 2 subjek kurang teliti dalam perhitungan sehingga terjadi kesalahan pada komanya. Akan tetapi subjek terlihat meggarisbawahi apa yang diketahui dalam soal, meenghubungkan apa yang diketahui dengan apa yang 
ditanyakan dalam soal setelah itu mengolah informasi untuk dapat menyelesaikan permasalah dalam soal tersebut terkait apikasi turunan.

\section{KESIMPULAN}

Berdasarkan hasil penelitian dapat disimpulkan bahwa proses berpikir proses berpikir matematis peserta didik dalam menyelesaikan masalah aplikasi turunan menggunakan beberapa tahap penyelesaian berupa : (1) menggaris bawahi apa yang diketahui dalam soal cerita, (2) menghubungkan apa yang diketahui dalam soal dengan apa yang ditanyakan, (3) Mengolah informasi yang diperoleh dari soal, sehingga akan lebih mudah dalam menyelesaikan masalah aplikasi turunan.

\section{DAFTAR PUSTAKA}

Dodi, Hudiono, B., \& Suratman, D. (2015). Analisis Keterampilan Berpikir Kritis peserta didik pada Materi Limit Fungsi Aljabar di Kelas X SMA. Jurnal Pendidikan Dan Pembelajaran, 4(8), 1-15.

Fatmawati, H., Mardiyana, \& Triyanto. (2014). Analisis Berpikir Kritis Peserta didik Dalam Pemecahan Masalah Matematika Berdasarkan Polya pada Pokok Bahasan Persamaan Kuadrat (Penelitian pada Peserta didik Kelas X SMK Muhammadiyah 1 Sragen Tahun Pelajaran 2013/2014). Jurnal Elektronik Pembelajaran Matematika, 2(9), 911-922.

NCTM. 2010. Why Is Teaching With Problem Solving Important To Student Learnig? www.nctm.org/.../Research_brief_14_- _Problem_Solving.pdf. diakses tanggal 20 Desember 2019

Rustaman, N. 2001. Ilmu dan Aplikasi Pendidikan. Bandung: Inperial Bakti Utama.

Santrock, John. W. 2004. Psikologi Pendidikan. Jakarta. Kencana-Prenada Media Group

Soedjadi, R. 2000. Kiat Pendidikan Matematika Di Indonesia. Konstatasi Keadaan Masa Kini Menuju Harapan Masa Depan. Jakarta: Direktorat Jenderal Pendidikan Tinggi, Departemen Pendidikan Nasional.

Sugiyono. (2014). Memahami Penelitian Kualitatif. Bandung: Alfabeta.

Widyastuti, R. (2015). Proses Berpikir Peserta didik dalam Menyelesaikan Masalah Matematika Berdasarkan Teori Polya Ditinjau dari Adversity Quotient Tipe Climber. Al-Jabar : Jurnal Pendidikan Matematika, 6(2), 120-132. 